\author{
Aleksei Lokhmatov \\ ORCID: 0000-0003-4070-403X \\ Department of History of Science, Universität Erfurt (Erfurt, Germany) \\ aleksei.lokhmatov@uni-erfurt.de
}

\title{
The academic virtues in public discussion: Adam Schaff and the campaign against the Lvov-Warsaw School in post-war Poland
}

\begin{abstract}
Adam Schaff was at the front of the ideological campaign organized in post-war Poland during the wave of Stalinization. By attempting to adapt the Soviet "model" of public discussion to Polish academia, Schaff wanted to teach the representatives of the Lvov-Warsaw School of logic how to lead a scholarly debate. Schaff's group consisted of young scholars from the Instytut Kształcenia Kadr Naukowych [Institute for Education of Scientific Staff] and with critical reviews on the works of Polish logicians they tried to force their opponents to change the basic principles of their academic practice under the new circumstances. Nevertheless, Schaff's project failed since, unlike Soviet scholars, the participants in the discussion referred to
\end{abstract}

\begin{tabular}{|c|c|c|c|c|c|}
\hline \multicolumn{2}{|c|}{$\begin{array}{l}\text { PUBLICATION } \\
\text { INFO }\end{array}$} & Pistoriae & $\begin{array}{r}\text { e-ISSN 2543-702X } \\
\text { ISSN 2451-3202 }\end{array}$ & 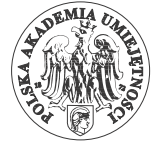 & $\begin{array}{l}\boldsymbol{\varnothing} \\
\text { DIAMOND } \\
\text { OPEN ACCESS }\end{array}$ \\
\hline \multicolumn{6}{|c|}{$\begin{array}{l}\text { CITATION } \\
\text { Lokhmatov, Aleksei The academic virtues in public discussion: Adam Schaff and the campaign against } \\
\text { the Lvov-Warsaw School in Post-War Poland. Studia Historiae Scientiarum 20, pp. 711-753. } \\
\text { DOI: } \underline{10.4467 / 2543702 X S H S .21 .021 .14052} \text {. }\end{array}$} \\
\hline \multicolumn{3}{|c|}{$\begin{array}{l}\text { RECEIVED: } 02.11 .2020 \\
\text { ACCEPTED: 08.07.2021 } \\
\text { PUBLISHED ONLINE: } 13.09 .2021\end{array}$} & $\begin{array}{l}\text { ARCHIVE } \\
\text { POLICY } \\
\text { Green SHERPA/ } \\
\text { RoMEO Colour }\end{array}$ & $\begin{array}{l}\text { LICENSE } \\
\qquad \text { (c) } \underset{\mathrm{BY}}{\text { (i) }}\end{array}$ & 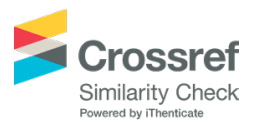 \\
\hline www & \multicolumn{5}{|c|}{ https://ojs.ejournals.eu/SHS/; http://pau.krakow.pl/Studia-Historiae-Scientiarum/archiwum } \\
\hline
\end{tabular}


different academic virtues that made the adaptation of the Soviet model of public discussion impossible.

Keywords: public discussions, academic virtues, Stalinism, Adam Schaff, the Lvov-Warsaw School, Polish philosophy

\title{
Cnoty akademickie w dyskusji publicznej: Adam Schaff i kampania przeciwko szkole lwowsko-warszawskiej w powojennej Polsce
}

\begin{abstract}
Abstrakt
Artykuł dotyczy kampanii ideologicznej prowadzonej przez Adama Schaffa, zorganizowanej w powojennej Polsce na fali stalinizacji. Próbując dostosować radziecki „model” dyskusji publicznej do polskiego środowiska akademickiego, Schaff chciał „nauczyć” przedstawicieli lwowsko-warszawskiej szkoły logiki, jak prowadzić debatę naukową. Pisząc krytyczne recenzje prac polskich logików, grupa Schaffa, w skład której wchodzili młodzi naukowcy z Instytutu Kształcenia Kadr Naukowych, próbowała zmusić swoich przeciwników do zmiany podstawowych zasad praktyki akademickiej w nowych warunkach. Niemniej jednak projekt Schaffa nie powiódł się, ponieważ, w przeciwieństwie do sowieckich uczonych, uczestnicy dyskusji odnosili się do różnych cnót akademickich, które uniemożliwiały adaptację „radzieckiego modelu” dyskusji publicznej.
\end{abstract}

Słowa kluczowe: dyskusje publiczne, cnoty akademickie, stalinizm, Adam Schaff, szkota lwowsko-warsqawska, filozofia polska

\footnotetext{
A conscience of an intellectual that is detached from the course of history is a broken compass. It is not to be trusted [...] History has drastically simplified the matter of choice. There is either the path of criminal capitalism or "socialist revolution".

Józef Chałasiński Rzecz zpowodu „Humanistyki bez bipostaz” (1952)
}

\section{Introduction}

I still cannot get used to the role of an important person who has to make daily decisions on issues that are important 
to other people. I am engaged in dancing among swords, wishing to give the University of Lódź a liberal face. ${ }^{1}$

With these words, the prominent Polish philosopher-logician Tadeusz Kotarbiński (1886-1981) described his first steps as rector at the newly established University of Lódź in September 1945. Kotarbiński, a representative of the world-famous Lvov-Warsaw School, was chosen to preside over the construction of the infrastructure of Polish academic institutions at a time of increased autonomy for the social sciences and humanities, immediately following the Second World War. The devastation of Warsaw made Lódź, at least for a short period, the academic capital of Poland. The project, which was called tagodna rewolucja [gentle revolution] in the cultural field, also found application in the academic landscape. The aspiration to soften rather than intensify internal contradictions was among the most important ideas of the early post-war years, and was intended to prevent resistance against establishing a new political regime in Poland. ${ }^{2}$ Particular autonomy of a scholarship holder, conditional upon following vague slogans of people's unity, "progressive ideas," and friendship with the Soviet Union shaped a space both for the reconstruction of the inter-war academic traditions destroyed by World War II, and for a certain optimism concerning the opportunity to use the new conditions to organize post-war Polish academia in a "more progressive way" than in the Polish Republic before 1939.

Nevertheless, the political situation soon changed: the Cold War and the subsequent Soviet Union's declaration of intolerance to liberal and nationalist biases' in socialist countries, ${ }^{3}$ contributed to unified approaches to science and scholarship. One of the projects, which was designed to demonstrate the unity of Polish science and scholarship, was the First Congress of Polish Science (1951). The preparations to this event started several years before the official ceremony in summer 1951. ${ }^{4}$ The preparatory meetings of the section for philosophy and the

1 Kotarbiński, Kuźnicka 2006, p. 26.

2 About his project see: Borejsza 1945, p. 1. The concept of the gentle revolution is referred to in the Polish historiographic tradition concerning the Constitution of the 3 May 1791, see: Wierzbicki 1993.; Ostrowski 1945, pp. 11-13.

3 Adibekov 1998, p. 300.

${ }^{4}$ Hübner 1983, pp. 73-87. 
social sciences testified to critical difficulties in reaching the desired unity among Polish scholars. The task to find a 'compromise' in 'the only scientific method' of Marxism-Leninism proved to be hardly possible for Polish academics, as Marxism, especially in its Soviet variant, was not only unpopular among scholars, but also stood in certain paradigmatic contradiction to the approach of the Lvov-Warsaw School, which shaped the agenda of the philosophical debates in the interwar period. ${ }^{5}$

Though the attempt to reach methodological unity within the First Congress of Polish Science was not entirely 'successful, ${ }^{6}$ the search for a scholarly tradition that would meet the constantly changeable political realities did not finish. The creation of the journal Myśl Filozoficzna (Philosophical thought) was a new step on the way to the 'correct' format of academic discussion under the conditions of the so-called Stalinization. The editor-in-chief of the new periodical, the Marxist philosopher Adam Schaff (1913-2006), became the "helmsman" of the campaign for the "correct" philosophy in Poland. In his aspiration to make the discussions in Myśl Filozoficzna an instrument to achieve unity under the banner of Marxism-Leninism, Schaff led the journal towards the Stalinist model of academic debates that he had learned during his philosophical studies in Moscow. ${ }^{7}$

This type of politics, and Schaff's active involvement in the process of Stalinization of Polish philosophy, aimed at forcing Polish scholars to adopt a new genre of scholarly discussion, with the Lvov-Warsaw School becoming the main target of harsh criticism in academic publications. Nevertheless, the peculiarity of the Polish context, recognized by Stalin from the beginning of the "Polish Soviet project," became a factor that constituted an essential difficulty. The leading role and international fame of Polish logicians, together with the rejection of extremely repressive methods of unifying Polish scholars were among the obstacles to be reckoned with by Schaff and his colleagues. In this way, Polish academics supervised by Schaff ${ }^{8}$ had to find a new balance in the presentation

${ }^{5}$ Lokhmatov 2020, pp. 522-523, 534-539.

${ }_{6}$ The final report of the Congress praised Marxism-Leninism, but still recognized the absence of a compromise in the methodological and theoretical approaches to understanding their corresponding research fields, see: [N.N.1] 1953, p. 110.

7 About Schaff's Soviet experiences, see below.

8 Adam Schaff loved to emphasize his leading position in establishing Marxism in Poland, see: Schaff 1997; Chwedeńczuk 2005, pp. 13, 14. 
of philosophical debates, a path which would help to demonstrate the reorientation of Polish academia towards the Soviet version of MarxismLeninism.

In this article, I intend to trace the development of the critical discourse directed against the heritage of the Lvov-Warsaw School and its key representatives in post-war Polish academia. In consideration of the extremely fluid political agenda after the Second World War, I will examine the campaign against the Polish logicians headed by Adam Schaff, and the responses of the Polish philosophers associated with the Lvov-Warsaw School ${ }^{9}$ to the criticism, making them a meeting point of the two different approaches to academic discussion. Recent tendencies in the history of science and scholarship associated with historical epistemology have led to particular attention from scholars not only to the social, political and cultural conditions of academic practice, but also to basic epistemic virtues, which determine the aims and conventions of scientific/scholarly research. ${ }^{10}$ Nevertheless, the general perspective of the history of science and scholarship is usually focused on the common virtues that should be relevant for all in the scientific/scholarly/academic discourse. ${ }^{11}$ It also does not cover the level of academic practice where the ideas of basic virtues, represented by various scholars, stay in fundamental contradiction to each other. The campaign against the Lvov-Warsaw School, which took place during the wave of Stalinization in Poland, represents a good example for such a clash.

Even though the organizers of the campaign, represented as an "academic discussion," enjoyed governmental support and even implemented a governmental program, the Polish logicians had the opportunity not only to answer the criticism but also to express disagree-

9 As will be shown in this text, some of them preferred to divide the Lvov and Warsaw school. Nevertheless, since the whole campaign was directed against the Lvov-Warsaw School, the Polish logicians were in 'the same camp.' Considering the perspective of this article, I will call them the representatives of the Lvov-Warsaw School, as is common for the literature on the intellectual heritage of the key protagonists of this text.

${ }^{10}$ See, for example: Daston 1994, pp. 282-289.

11 The most prominent work in this his area is the book of Lorraine Daston, and Peter Galison on the epistemic virtue of objectivity, see: Daston, Galison 2007; regarding the history of the humanities, see e.g.: Paul 2011, pp. 104-116; Paul 2019. 
ment to most of the arguments of their opponents. Since the prototype for this campaign, the Soviet academic debates, did not entail such a scenario, the Polish case could be of interest to scholars researching the Soviet culture of academic discussion as an attempt to adapt the Stalinist academic realities to the unpromising soil. Additionally, such a historical approach to the discussion between philosophers could open up a new perspective on the issues that were not central to the historians of philosophy who prepared plenty of insightful publications on the history of the Lvov-Warsaw School, ${ }^{12}$ and even covered certain aspects of the debates that will be discussed further in this article. ${ }^{13} \mathrm{My}$ key question is not about the object of this discussion or the arguments of both sides of the debate, though this issue will be discussed in this article. The main question is why this discussion was not and could not be successful in bringing the opposite positions together through an exchange of arguments and, thus, what can we learn from this discussion about the intellectual realities of the time, and about the motivation of the participants. By complementing the institutional approach to research on "Polish Stalinism," this article will argue that it was not the new institutions, but rather the special form of public discussion that was an essential prerequisite for the 'success' of Stalinization. ${ }^{14}$ The

12 See, for example: Garrido \& Wybraniec-Skardowska 2018; Drabek et al. 2019; Brożek \& Chybińska 2016.

13 About the debates which preceded the discussion examined in this article, see: Kojko 2009, pp. 101-144. About Leszek Kołakowski’s criticism against the conventionalism of Kazimierz Ajdukiewicz, which was a part of the campaign against the Lvov-Warsaw School, see: Juchnowski 2019, pp. 54-72. The prominent Polish and French philosopher Krzysztof Pomian wrote about this discussion in his autobiographic book: Pomian 2018, pp. 560-576. See also about the issue of student vs. professor relations: Salmonowicz 2003, pp. 75-92; see also: Zegzuła-Nowak 2010, pp. 257-266.

${ }^{14}$ John Connelly's research on Polish Stalinism is one of the most famous examples of an institutional approach to this issue in English language literature. The institutional perspective on Stalinization and a superficial reference to the campaign against the Lvov-Warsaw School led Connelly to the idea that Stalinization 'failed' due to the fact that Schaff wanted to attract 'old professors' to his project. In turn, Schaff is represented as a figure looking for a compromise considered undesirable by the authorities (Connelly 1996, p. 333). The argument of my article is that a special form of public discussion -one that implied public self-criticism of those who became the subjects of public criticism - was an integral part of the Soviet 'model' that Schaff 
"failure" of the project to adapt to the new virtues of the academic discussion resulted in the institutions created by Stalinism becoming bastions of resistance to the principles of "Stalinism" during the wave of de-Stalinisation. This context made the campaign against the LvovWarsaw School one of the fundamental events in the formation of the academia of the post-war Poland.

\section{Adam Schaff and preparations of a platform for the 'official' philosophy}

The Marxist philosopher Adam Schaff (1913-2006) was one of the key figures for the post-war Polish academic and politic landscape. He was born in Lviv (then Lwów, Poland) to a Jewish family and would recall later that it was antisemitism in his native milieu that was among the reasons why he became fascinated with communism in his youth. Having graduated from the University of Lviv, he moved to the Soviet Union to study philosophy at Moscow State University. ${ }^{15}$ Having finished his study and received a doctoral degree, Schaff came back to Warsaw in 1948, when academic and cultural life had already been reconstructed after the devastations of the war. Nevertheless, Schaff immediately started to play an important role in the increasing intersection of politics into Polish academic practice. Against the backdrop of the beginning of Stalinization in Polish academia after 1948, knowledge of the Soviet academic realities was an extremely valuable asset. Having such a person on the board was important, first of all, for the leaders of the Polish United Workers' Party, who, on the one hand, had previously left academic issues for scholars to discuss, and on the other, had a very limited idea of the current Soviet academic landscape, which was to became an ideal model for unifying the Polish scholarship. ${ }^{16}$ In 1950,

attempted to apply in the Polish context. Thus, the focus of this article rests not on the compromise but on the clash of opposite virtues within Polish academia.

15 About the formative years of Adam Schaff and his early experiences with communism, see: Kuryła 2018, pp. 167-189.

16 Schaff remarked later that Bolesław Bierut (1892-1956), who became the leader of the Polish Workers' Party after the accusation against Władysław Gomułka (1905-1982) of nationalist bias, deeply appreciated the competencies of Schaff; see the interview with Adam Schaff 2003. 
Schaff organized the Instytut Kształcenia Kadr Naukowych (IKKN) [Institute for Education of Scientific Staff], which was to start preparing an alternative intellectual elite for Polish universities and research institutes. ${ }^{17}$ With his direct contact with the party leadership, Schaff tried to unify Polish academia under the banner of Marxism-Leninism. ${ }^{18}$

The problem with the Lvov-Warsaw School became obvious from the beginning of the process of Stalinization: not only the inter-war achievements of its representatives, but also the fact that most prominent Polish philosophers, such as Tadeusz Kotarbiński, Władysław Tatarkiewicz, and Kazimierz Ajdukiewicz, already had senior positions in post-war Polish academia and did not see any fundamental contradictions with the vague slogans of 'people's democracy' in their post-war academic activity. This problem became more evident during the discussions about the 'progressive intellectual tradition' at the scientific congress of 1951. It was there that the representatives of the prominent school of logic first heard - from Schaff himself - the 'official' accusations against Polish logical positivism and their 'conventionalist, non-historical, and non-sociological' attitude. Nevertheless, since the main slogan of this congress was to gather the best scholars and to let them define the most progressive tendencies in their research fields, the Polish logicians still thought that the discussion was an exchange of opinions and publicly disagreed with their critics. ${ }^{19}$

From his Soviet studies, Schaff knew that there could only be one correct philosophy in the country, but the weakness of his position forced him to prepare a platform for the reformation of the Polish academic landscape. Since the main Polish philosophical journal Przeglad Filozoficzny [The Philosophical Review] had been closed by the authorities

17 See: Bińko 1996, pp. 199-214.

18 This article covers the period in which Schaff led the campaign for the Stalinization of Polish academia. It should nevertheless be mentioned that Schaff was not always in the dominant position to enjoy support of the authorities. During the antisemitic campaign of 1968, he became the subject of a smear campaign due to his Jewish origin. More importantly, Schaff became one of the most famous Marxist thinkers from the socialist bloc whose works were well accepted, to take one example, by the Frankfurt School. The complex intellectual biography of Adam Schaff still requires further research.

${ }_{19}$ See the minutes of the Congress discussion from the privet archive of Nina Assorodobraj-Kula: Rps BUW nr aks 4228, I Kongres Nauki Polskiej, K (2-5). 
in 1949, the journal Myśl Filozoficzna, edited by Schaff, became the main philosophical periodical. In his editorial article, ${ }^{20}$ Schaff introduced the new program of philosophy to the Polish audience, which was actually still only an ideal to reach during academic debates. Soviet philosophy was a part of politics and ideology, but it was not obvious from the perspective of the former academic tradition in Poland, and Schaff had to explain the basic principles to Polish scholars:

The world is divided into two camps. On one side: the camp of peace and socialism headed by the Soviet Union, $[\ldots]$ which attracts millions of ordinary and honest workers around the world. On the other side: the imperialist camp trying to start a new military conflagration in the interests of the Anglo-American aggressors [...], a camp that wants to stop and reverse the development of the world in order to save dying capitalism. ${ }^{21}$

From this passage, it was clear that there are two kinds of philosophy - the bourgeois one and the 'correct' one. In this case, the place of Polish academia seemed to be problematic, since they had earlier seen themselves as a part of the European academic landscape with a more uncertain look towards the Soviet Union. Nevertheless, Schaff, whose talent to explain the changeable realities from the "correct point of view" would play a role in the history of modern Marxism, ${ }^{22}$ found a definition for the current status of the Polish nation and, thus, its scholarship. Whereas the romantic thinker Maurycy Mochnacki (1804 -1834) thought that intellectual self-discovery was a prerequisite for

20 There is no author in the article entitled 'From the Editorial Board,' but the listed members of the editorial board as well as the content of the text show that this article was highly likely to have been written by Schaff himself.

21 [N.N.2] 1951, p. 7.

22 Prof. Boris A. Filippov, who worked for the Institute of Scientific Information on Social Sciences of the Russian Academy of Sciences (INION), and was responsible for writing reviews on the Polish academic literature, told me about the helpfulness of Schaff's publications with answering uncomfortable questions. When giving a lecture to the officers of the border guard in the Far East, prof. Fillipov was able to answer a direct question from one of the generals: 'Is China a socialist state or not?' The knowledge of Schaff's publications allowed Fillipov to say that China had a socialist foundation and a bourgeois superstructure. The general was fully satisfied. 
people in Poland to become a Polish nation, Schaff was sure that selfconsciousness would lead them to socialism. ${ }^{23}$ Even though the Polish nation, according to Schaff, was still far from this ideal, he did not lose optimism when arguing that Poles "would rebuild themselves from a bourgeois nation to a socialist one." 24

Referring to the Stalinist definition of a nation as "a unity of territory, language, and historically formed psychological structure," Schaff had to recognize the problems with "true socialism" in the "Polish psychological structure." Nevertheless, the lack of success in finding a Polish "progressive intellectual tradition" within the first scientific congress did not confuse Schaff, who, based on quotations from the works of Vladimir Lenin, argued that every nation has two cultures: a democratic-socialist one and a bourgeois one. ${ }^{25}$ In such a way, the aim of Poland was to win the fight between the bourgeois and the socialist world within her own nation. Schaff expected a cruel battle. During the ideological campaign against sociology in Poland, which- following Soviet Union's modelwas banned as an academic discipline, he used the fate of this discipline as an inspiration for the struggle against the "wrong" views:

The necessary condition for the success of this work [towards unification of philosophy] is a critical analysis of the foundations of Polish academic sociology, whose research activities had been burdened with false ideological and methodological assumptions. ${ }^{26}$

Throwing down the gauntlet, Schaff wrote:

Without uprooting the relics of bourgeois consciousness, without fighting against political, legal, moral, philosophical, and aesthetic bourgeois opinions, without the victory of the new views and the ongoing strengthening of new institutions that would quickly meet the needs of the socialist base, without the constant development of socialist consciousness, the socialist nation cannot crystallize $[\ldots]^{27}$

23 "socialism" was, in this case, a slogan from the Stalinist vocabulary.

${ }^{24}\left[\mathrm{~N} . \mathrm{N}_{2}\right]$ 1951, p. 8.

${ }_{25}\left[\mathrm{~N} . \mathrm{N}_{2}\right]$ 1951, pp. 8-9.

${ }^{26}\left[\mathrm{~N} . \mathrm{N}_{2}\right]$ 1951, p. 12.

${ }^{27}$ [N.N.2] 1951, p. 10. 
The emphasis on the necessity to create and promote new academic institutions was not an accident. Besides the Marxist methodological background of this idea, Schaff, a participant in the unfortunate quest for unity in alliance with the representatives of the Lvov-Warsaw School, ${ }^{28}$ obviously understood that the success in reaching this unity did not depend on what was being searched for but on who was looking for it.

Since the editorial board did not strive to immediately exclude all nonMarxists from the public debate, the first manifesto of the new philosophical journal outlined its attitude to the lack of unity within the Polish academia. Though the ultimate aim of the journal was not to imply any plurality but "to imbue the whole of Polish science with a Marxist-Leninist worldview," ${ }^{29}$ the quotations from Lenin helped the editors to argue that, at the early stages, collaboration with nonCommunist scholars was possible. Such generosity was not, of course, unconditional. The collaboration ultimately depended, according to the editorial article, upon the readiness of the non-Marxist scholars to become Marxists. It is difficult to imagine that Schaff had been considered a significant figure among prominent philosophers such as Kotarbiński, Tatarkiewicz, and Ajdukiewicz, ${ }^{30}$ but in 1951, he kindly offered them ${ }^{31}$ "assistance [of the editorial board of the journal] on the way to Marxism. ${ }^{32}$ Moreover, "a thorough assessment of the LvovWarsaw School" from the Marxist point of view was described as one of the key tasks of Myśl Filozoficzna. ${ }^{33}$

In such a way, the humanities, according to Schaff's plan, had to become not just "cabinet disciplines for chosen people" but an instru-

28 The matter concerns again the First Scientific Congress, to which all key representatives of non-Marxist philosophy were invited (see the lists of participants of the congress: Archiwum PAN, I Kongres Nauki Polskiej, Sygn. 13, K. 110-115; K. 71-78.)

${ }^{29}\left[\mathrm{~N} . \mathrm{N}_{2}\right]$ 1951, p. 11.

30 After Schaff's return from the Soviet Union, Kotarbiński considered his Soviet degree insufficient for receiving a professorship in Poland and thought that a 'Western' habilitation was required (Connelly 1996, p. 326.)

31 After disbanding sociology, the logical positivists were key representatives of 'non-Marxism'

32 [N.N.2] 1951, p. 13.

33 [N.N.2] 1951, p. 15. 
ment in the hands of the "peasant masses." Having witnessed the beginning of a new wave of Stalinist repressions, conducted under the banner of a struggle against cosmopolitanism, ${ }^{34}$ Schaff repeatedly ensured the readers that there was no place for cosmopolitan attitude in Poland, and remarked that Anglo-American imperialism was, at the time, the stronghold of cosmopolitanism. ${ }^{35}$ The editorial board ensured the readers that the new Polish philosophy would go perfectly well without the Western bourgeois sciences: on the one hand, there was the brilliant example of the Soviet Union for Poland to admire, on the other hand, the special research campaign for discovering the Marxist tendencies in the non-Marxist Polish past was to make Poles proud of their country. ${ }^{36}$

Schaff knew better than many others in Poland that Stalin, who took to heart the increasing conflict with the Western alliance, applied this emotion to the cultural and academic fields. The relative liberalization of the Soviet cultural realities in the last years of the war and immediately after, threatened the principles Stalinism was based on. ${ }^{37}$ Besides the antisemitic aspects of the post-war struggle against cosmopolitanism, Stalin was not pleased with the tendency of Soviet artists, writers, and scholars to value their contacts with Western colleagues, from whom they had been separated for several years since Stalin's rise to power and until the foundation of the anti-Nazi alliance during World War II. The most notorious smear campaign against the writers Anna Akhmatova and Mikhail Zoshchenko in 1946 was a signal that a fascination with 'Western culture' was not welcomed in the Soviet Union.

Since Stalin in person 'supervised' both cultural and academic areas of Soviet intellectual life, ${ }^{38}$ the campaign against the superstar of Stalinist philosophy Georgy Aleksandrov (1908-1961) and his textbook History of Western Philosophy (1946) became the most noticeable campaign to

${ }^{34}$ In fact, this was instead an antisemitic campaign that used the slogans of 'patriotism' and 'native culture,' and was associated with the struggle against 'Western influences.' See: Pinkus 1974, pp. 53-72.

35 Using the Soviet terminology in the Polish context, Schaff referred to the concept of cosmopolitanism, first of all, as a tool of the struggle against the "Western influences," i.e. the influences of the enemies of the Soviet Union.

${ }^{36}$ [N.N.2] 1951, p. 15.

37 Zubkova 1998, pp. 99-148.

38 Stalin liked 'editing' even school textbooks, see: Khlevniuk 2015, p. 94. 
discipline the Soviet humanities after the war. ${ }^{39}$ Aleksandrov's book was initially awarded with the Stalin prize (November 1946) but several weeks later, Stalin expressed his displeasure with some theses from the book. The Soviet ideologist Andrei Zhdanov (1896-1948), during an open discussion, criticized, among other things, Aleksandrov's lack of understanding that Marxism divided philosophy into "before" and "after" periods, ${ }^{40}$ his disregard for Russian philosophy, which gave an impression that Marxism was only a Western phenomenon, ${ }^{41}$ and, more importantly, the "vegetarianism" towards bourgeois philosophers whom Aleksandrov, according to Zhdanov, 'burned incense for' at every opportunity. ${ }^{42}$ Of course, the 'open discussion' 'convinced' Aleksandrov that he was wrong and he apologized for his views. ${ }^{43}$ Adam Schaff was in the epicenter of this debate during his studies in Moscow. More importantly, the campaign against Aleksandrov was the most obvious example of how to lead an academic discussion to reach unity at the end. The challenge was to apply this kind of discussion to the Polish soil, which was not welcoming to that kind of seed.

\section{The idealistic character of non-Marxian materialism: Tadeusz Kotarbiński}

Since Adam Schaff took his task to make Polish academia Marxist very seriously, the neutralization of the Polish logicians was a significant challenge on his way. The first blow against the Lvov-Warsaw School was dealt by one of his students. Bronisław Baczko (1924-2016), later an emigrant and a French historian of ideas, who became one of the first fellows at the IKKN. The young officer Baczko was sent to Schaff's institute on military orders, showing great promise. Tadeusz Kotarbiński, as a key representative of the logical tradition in post-war Poland, became the first target of the campaign. Following the slogans of the first scientific congress, Baczko formulated the aim of his publication as 'analyzing the views of the Lvov-Warsaw School from the

39 Aleksandrov 1946.

40 Zhdanov 1952, pp. 12-13.

${ }^{41}$ Zhdanov 1952, p. 14.

42 Zhdanov 1952, p. 17-19.

43 Kojevnikov 1998, pp. 28-40. 
Marxist point of view.' It helped him to make it clear that every student of Schaff's institute knew that there were only two types of philosophy materialist and idealist ones - thus, the first task of Baczko was to find out to which camp Kotarbiński really belonged. Additionally, it was necessary to specify Kotarbiński's attitude to the process of "forging the Polish nation into a socialist one." ${ }^{44}$

To find idealism in the works of Kotarbiński, who, since the interwar period, had declared his materialist attitude, was not an easy task, but the fact that the logician was not a Marxist inspired Baczko in his search. The concept of reism (from Latin: res = thing), which described Kotarbiński's program of rationalization of the academic discourse, became the object of Baczko's examination. Being a part of the European logical movement, Kotarbiński thought that rational reductionism in the language used for academic communication, i.e. speaking in non-ideological and concrete language, would help to resolve most of philosophical contradictions. Thus, according to Kotarbiński, "good semantics would be a good treatment" 45 for contemporary philosophy. This program gave Baczko a good argument with which to accuse Kotarbiński of reducing the essential philosophical issues to the matter of language and, thus, making philosophy a "façon de parler" but not a science about objective laws of social and economic development, which it should be according to Marxism-Leninism. This was not only philosophical misconduct but "opening the doors to idealism":

any blurring of the basic dividing line in philosophy and introducing some additional dividing lines depending on the acceptance of one or another 'language' [...] makes the path of idealism easier, makes smuggling of idealistic ideas under the banner of 'a language of things' easier. ${ }^{46}$

This argument became central in Baczko's text and helped him to argue that the relativism of Kotarbiński concerning the objective issues

${ }^{44}$ Baczko 1951a, pp. 247-248. The publication of Baczko was a summary of his small book which was published by the institute of professional training - Baczko 1951b. Nevertheless, since the publication in Mysl filozoficzna was a part of the discussion that is central in this article, the quotes (and translate) come from this philosophical journal.

45 Kotarbiński 1925, p. 124.

46 Baczko 1951a, pp. 250-251. 
of philosophy led him to act in favor of "idealist forces." The writings of Stalin allowed Baczko, on the one hand, to show that Marxism supported the clarity of words but not the fetishization of language, and on the other hand, to highlight the danger of "idealist semantics" which was used by "reactionary idealist philosophers" to fight against materialism. ${ }^{47}$ In such a way, according to Baczko's logic, Kotarbiński’s approach to language was, in fact, "conventional," and conventionalism was - as every Marxist had to know - the main bastion of idealism. The young Marxist Baczko was strict and, at the same time, indulgent towards the prominent professor Kotarbiński:

it can be thought that, subjectively, Prof. Kotarbiński himself would not accept extremely conventionalist views. However, this does not change the objective fact that the conventionalist conclusions, which had been rejected by Prof. Kotarbiński, could be consistently derived from his views. ${ }^{48}$

Thus, though unaware of it, Kotarbiński, according to Baczko, supported idealism while believing himself to be a materialist.

Since Kotarbiński misunderstood his own ideas, Baczko explained the idealist nature of the materialistic concept of pansomatism, which played a key role in Kotarbiński's interwar writings. With this concept, which was formed from the Greek words $\pi \dot{\alpha} \nu$ (pan - everything) and $\sigma \dot{\omega} \mu \alpha$ (soma - body), Kotarbiński attempted to represent all objects in the word as bodies and argued that only they possess "real existence," while "the whole reality is formed by bodies." ${ }^{49}$ This concept was a part of Kotarbiński's program aimed at the rationalization and concretization of scientific discourse: the examination of all phenomena in the world as 'bodies,' i.e. separate and concrete things, had to help to avoid confusion regarding the objects of academic debates. ${ }^{50}$ Nevertheless, Baczko exposed this way of thinking and argued that this program, in fact, also led its followers to the "sin of verbalism."

47 Baczko 1951a, pp. 252-254.

48 Baczko 1951a, p. 257.

${ }^{49}$ Kotarbiński 1935, p. 289.

${ }^{50}$ See: Kotarbiński 1929.

51 By the sin of verbalism, the author obviously meant the neglect of essential philosophical questions and replacing them with speculations on words. 
to him, "by striving to defend materialism, Prof. Kotarbiński thought that nominalism ${ }^{52}$ could effectively fight verbalism, and thus, undercut the roots of idealism," but the idealist elements of this theory, Baczko wrote, made the whole program groundless.

Kotarbiński himself was aware of the limitations of pansomatim. He argued that his key thesis that "there is nothing that could not be grasped by reason" was only a hypothesis based on his "assumption" and he did not see any possibility to prove this statement properly. ${ }^{53}$ This method of defending materialism, as well as all other forms of doubts, were foreign to Marxism-Leninism: Baczko argued that following one's own suggestions in philosophy is nothing but a form of subjectivism, which could not be tolerated under the new conditions. Having discovered such a statement in the writings of Kotarbiński, Baczko did not have any further problems with exposing the idealist nature of his opponent's attitude. The assumption of subjectivism in philosophy meant, in fact, conventionalism, which was, as Baczko wrote, an idealistic program and one of forms of subjective idealism." ${ }^{54}$ Since Baczko was a good student of Schaff's institute, he had very concrete criteria for the classification of philosophical ideas. As there was only materialism and idealism in philosophy, all "intermediate forms" could be classified as belonging to either one or the other camp. To be more precise, after the appearance of Marxism, all other philosophical programs lost their relevance because they did not propose a more radical materialist agenda than Marxism.

Since the political reality was also seen by Baczko through the prism of competition between idealism and materialism, a drop of idealism could spoil the whole materialist program, and which would play into the hands of the enemy. Baczko referred to Lenin's version of the reflection theory, which claimed that people reflect objective reality in their minds and correct intellectual work is nothing but comprehending this objective reality. This uncompromising approach did not contain any

52 Nominalism is a philosophical term rooted in the medieval discussions on the 'problem of universals.' Generally speaking, nominalism denies the existence of universals and abstract objects, but affirms the possibility of finding a correct predicate to objects.

${ }^{53}$ Kotarbiński 1929, pp. 97-98.

${ }^{54}$ Baczko 1951a, p. 263. 
idealism and, according to Baczko, perfectly resolved all the vacuous philosophical questions Kotarbiński was aware of. ${ }^{55}$ Since the theory of Lenin was the pinnacle of progressive thought, the lack of Lenin's cognitive optimism in the works of Kotarbiński appeared to be a sign of backwardness. When the ultimate aim of philosophy was to destroy idealism, the basic virtue both of the philosopher and the theory was the effective struggle against the enemy. This was a virtue that, for understandable reasons, was absent in Kotarbiński's research program.

After the idealistic nature of Kotarbiński's philosophy had been exposed, Baczko came to the obligatory part in the new genre of academic debates, i.e. the examination of the 'social-political attitude' of the scholar under scrutiny. In the interwar period, Kotarbiński published his articles in the journal Racjonalista [Rationalist] and was among active fighters against metaphysics and irrationalism both in academic and in public debates. Baczko found many "praiseworthy" traits in the public activity of Kotarbiński in the past and especially emphasized his courage in the struggle against "fascism and Catholic obscurantism." His atheism, his materialistic claims, his fight against antisemitism in the universities, and the opposition to Józef Piłsudski's regime were, without doubt, "relatively progressive" for the interwar Polish realities. Nevertheless, from the Marxist point of view, all this did not seem to be innovative, Baczko wrote bacause all these elements were inherent in the program of the Bolsheviks. Compared to the Russian communists, the liberalism of Kotarbiński was, according to Baczko, already outdated in the interwar years. The aspiration of the philosopher to distinguish his "liberalism of intelligentsia" from the movement of the worker masses was a sin of backwardness even for the political realities of the Second Polish Republic. ${ }^{56}$

More importantly, the main problem with Kotarbiński after the war was that he did not change his views in the new realities. This point would be one of the key elements of the new genre of academic discussion. Baczko recognized that "there were certain points in the philosophical and social views of Kotarbiński that could lead to an evolution towards dialectical materialism, towards rejection of his

55 Baczko 1951a, pp. 269-275.

56 Baczko 1951a, pp. 260-261, 281-287. 
anachronistic individualistic liberalism [...] unfortunately, Baczko stated, such an evolution has not taken place until now." While the misconceptions of the past could be forgiven because of the "relative progressiveness" of Kotarbiński's views, his perseverance in defending outdated ideas under the conditions of the victory of socialism in Poland was not acceptable. "As a whole, as a system, the philosophical and social views of Prof. Kotarbiński remained out of the way, fenced off from those ideological changes that have been occurring in our reality, in our scholarship, among our intelligentsia," Baczko wrote.

There is a task that Polish philosophers are facing now Baczko continued - they should overcome all obstacles and barriers, all relics of idealism... [Polish philosophers should contribute] to the great struggle for peace and the Six-Year plan, the struggle for the future of our fatherland. ${ }^{57}$

The case of Kotarbiński was, according to Baczko, only one example of resistance among Polish philosophers to the progressive changes in Polish academia, and his publication was to "help" the prominent professor to understand his mistakes and take a step towards the most progressive ideological and research program, i.e. to Marxism-Leninism.

\section{Adam Schaff and "the radical conventionalism" of Ajdukiewicz}

The mentor of the campaign against the Lvov-Warsaw School, Adam Schaff, took over the analysis of the philosophical and ideological misconceptions of another prominent logician, Kazimierz Ajdukiewicz. The structure of his speech against Ajdukiewicz, delivered at the IKKN, which made the core of his publication in Myśl Filozoficzna, showed the consistency and discipline inherent in his approach to the fight against ideological enemies. When Kotarbiński openly claimed that he was a materialist, an atheist, and believed in the possibility of finding a rational explanation for all phenomena, the task of Schaff's crew was to explain why, without Marxism-Leninism, these beliefs of Kotarbiński were only an illusion. The case of Ajdukiewicz appeared to be much

${ }^{57}$ Baczko 1951a, p. 289. 
easier. In the interwar period, Ajdukiewicz was among those scholars who questioned the optimism of Kotarbiński regarding the possibility of finding a non-conventional method of rational argumentation. Ajdukiewicz's argument was that every language is a kind of convention, and it would be highly problematic to find a meta-language for the rationalization of academic discourse. It did not mean for him that rationalization was a futile project; on the contrary, Ajdukiewicz - as with many European logicians of his time - was deeply involved in linguistics and had attempted to find a linguistically acceptable method of rational argumentation.

Nevertheless, the word conventionalism was marked in the vocabulary of Schaff's group and meant, in fact, idealism. Additionally, Schaff did not see any signs of repentance in the post-war discourse of his opponent and started with a regret on this matter: "Ajdukiewicz is a conventionalist tout court, and he is a radical conventionalist. The line of his development is clear and remains unchangeable: Ajdukiewicz was a conventionalist in the interwar period [...] [he] has not changed his attitude now." 58 Adam Schaff then introduced a new element to the criticism against the Lvov-Warsaw School, which would play a significant role in the development of the campaign. As an objective of his publication, Schaff planned not only to criticize the views of Ajdukiewicz, but also to expose the "myth of scientific exactness," which surrounded the whole school. The issue also had political relevance, since the "esoteric mist" of the approach of the logicians had, according to Schaff, an extremely negative influence, not only on Polish academia, but also on Polish intelligentsia. ${ }^{59}$

Schaff understood that the "scientific exactness" and the rationalization of the academic discourse were the key points of the program of the Lvov-Warsaw School. Nevertheless, "Marxism teaches us," he argued, "that one should examine individuals and social groups not according to what they say or think about themselves, but according to what role they are objectively playing." Schaff saw the foundation of the "myth of exactness" in the references of logicians to mathematics. The abundance of mathematical equations played, in his view, a significant

58 Schaff 1952, p. 210.

59 Ibidem. 
role in creating a "smoke screen" around their argumentation. The critical and "objective" Marxist position of Schaff allowed him to show that all mathematical formulae, in fact, are merely disguised idealistic semantics, conventionalism and, thus, bourgeois ideology. Historically, according to Schaff, the Lvov-Warsaw School was at the center of bourgeois influence. Among the negative influences that shaped the bourgeois profile of the school, there was the English empiricism embodied by Bertrand Russell, the Austro-German neopositivism of Moritz Schlick (1882-1936), Rudolf Carnap (1891-1970), Otto Neurath (1882-1945), and the American pragmatism in the person of Charles W. Morris (1901-1979). From Schaff's perspective, all these approaches represented the "idealistic semantics" that characterized Ajdukiewicz's camp. ${ }^{60}$

This deductive strategy helped Schaff to represent Ajdukiewicz as a typical representative of the European "bourgeois ideology." Since the contacts of Ajdukiewicz with the Vienna Circle and Austrian logical positivism were an important point in his own representation of the international relevance of Polish philosophy, Schaff used this fact for the re-orientation of the reader towards another "source of truth" and strove to show that the example of the Soviet Union could help to get rid of "the original sin of idealism" in Polish academic practice. According to Schaff, nothing could expose better the "fetishization of language," which was so typical for Ajdukiewicz, than Stalin's famous article Marxism and Problems of Linguistics. ${ }^{61}$ Stalin explained that language was a social phenomenon and a communication medium which made useless any reflections on language without a concrete social context. Additionally, the research of the great Soviet physiologist Ivan Pavlov (1849-1936) perfectly proved Lenin's version of the reflection theory, which proclaimed objectivity in understanding the world and was only one more piece of evidence of the fruitlessness of Ajdukiewicz's speculations on the possibility of a rational language. ${ }^{62}$

Since it was not Schaff's aspiration to specify what Ajdukiewicz meant by his reflections on language, and his aim was instead to find idealism in the works of the "reactionary philosopher," Ajdukiewicz's

\footnotetext{
${ }^{60}$ Schaff 1952, p. 212.

${ }^{61}$ Stalin [1950].

${ }^{62}$ Schaff 1952, pp. 222-224.
} 
criticism of semantical idealism ${ }^{63}$ was wittily characterized by Schaff as "a family dispute." ${ }^{64}$ The German publications of Ajdukiewicz also attracted Schaff's special attention. In these works, Ajdukiewicz put special emphasis on the differences in languages and untranslatability of some speech forms that play an important role in communication. Additionally, he referred to the fact that languages determined the perception of the world and hypothesized the possibility of the coexistence of different visions of reality. ${ }^{65}$ It was enough for Schaff to refer to the "complete scientific crash" of Ajdukiewicz, who had relativized the objectivity of reality. Such relativism, wrote Schaff, opened the door not only to some forms of idealism, but also to the most obscure forms of knowledge such as "fairy tales, superstitions, and religious miracles." ${ }^{\prime 66}$

Nevertheless, the main section in the "academic criticism" of the new genre referred to the current views of Ajdukiewicz. Liberalism and the struggle against fascism in the interwar period became for Schaff extenuating circumstances for the misconceptions of Ajdukiewicz, ${ }^{67}$ as it was in the case of Kotarbiński. Following the same tried and tested pattern, Schaff turned to the discussion on Ajdukiewicz's attitude under the new political conditions of post-war Poland. The review of philosophical tendencies, which was published by Ajdukiewicz in 1946, ${ }^{68}$ provoked a remark characteristic of Schaff, which demonstrated his axiology:

Socialism has won, [and] the role of Marxist ideology has changed in Poland; the scientific Marxist criticism of positivism has reached us (apparently in the face of Schaff himself - A.L.). Nevertheless, Ajdukiewicz discussed the position of neopositivism not only with an "academic objectivity," without a hint of criticism, but also with sympathy and with affirmative points, with approval. ${ }^{69}$

${ }^{63}$ Ajdukiewicz 1937, pp. 271-287.

${ }^{64}$ Schaff 1952, pp. 228.

${ }^{65}$ The matter concerned first of all the publications: Ajdukiewicz 1935, pp. 22-30; Ajdukiewicz 1934, pp. 100-138.

${ }^{66}$ Schaff 1952, pp. 239-240.

${ }^{67}$ Schaff 1952, p. 253.

68 Ajdukiewicz 1946, pp. 155-176.

${ }^{69}$ Schaff 1952, p. 252. 
The fact that Ajdukiewicz failed to comprehend the superiority and universality of Marxism-Leninism when the capitalist regime in Poland had been broken was his main and unforgivable mistake. Schaff conducted a detailed examination of the post-war publications of Ajdukiewicz to prove the fact that his opponent did not change his mind after the war, although Ajdukiewicz had never tried to argue against this. Nevertheless, Schaff ruthlessly exposed a simple fact that was to complete the defeat of his opponents, i.e. writing that, even though the Vienna Circle did not exist anymore, its members had left for the USA and England, and thus their intellectual agenda had become "the flagship philosophy of world reaction." "The bourgeoisie is well aware of the mobilizing power of Marxist theory," Schaff wrote, "therefore, the ideological fire of the bourgeoisie is directed against it." "70

In such a way, the Lvov-Warsaw School was represented as an agent of world imperialism in the young Polish socialist state. Nevertheless, Schaff did not want to be unfair towards Ajdukiewicz and claimed that his opponent never wanted to defend obscurantism but sincerely believed in the rationality of his research program. Moreover, Schaff expressed certain empathy towards the representatives of the Lvov-Warsaw School: "Psychologically, the indignation of people who believed in the scientific myth of their position is quite understandable when this myth has been exposed. Nevertheless, this is the truth, and no indignation can help against this truth." In conclusion, Schaff clarified what he understood by the "discussion" that the new philosophical journal had been created for. In his view, only two kinds of discussion were possible in the socialist land, i.e. criticism of nonMarxist views, and self-criticism of those who represented those incorrect views. ${ }^{71}$

${ }^{70}$ Schaff 1952, p. 254.

${ }^{71}$ Schaff 1952, p. 256. About the Soviet culture of self-criticism, see.g.: Matveev 2020, pp. 113-124. It is noteworthy that the communist journal Nowe Drogi $\mathrm{New}$ paths] published a special article on "criticism and self-criticism" in the subsection Consultations: Budzynska 1952, pp. 117-127. 


\section{Blow against the foundation of the Lvov-Warsaw School: Kazimierz Twardowski}

The blow against the founder of the Lvov-Warsaw School, Kazimierz Twardowski (1866-1938), was supposed to complete the ideological destruction of the non-Marxist milieu in Polish academia. The young fellow of Schaff's institute, Henryk Holland (1920-1961), who conducted the examination of the works of Twardowski from the Marxist point of view, had already had an experience in "improving" Polish university teaching. Together with Leszek Kołakowski (1927-2009) and some other young intellectuals, he belonged to the group of the members of the Polish United Workers' Party that had organized a student protest against the teaching strategy of yet another representative of the Lvov-Warsaw School, Władysław Tatarkiewicz. During a seminar, on behalf of his colleagues, Kołakowski read out their letter with accusations against Tatarkiewicz concerning his "hostile claims against Poland constructing socialism," ${ }^{72}$ and the professor was suspended from teaching at the University of Warsaw. ${ }^{73}$ Two years later, Holland continued the public struggle against the "myth" of the LvovWarsaw School and exposed the "legend of Kazimierz Twardowski." "74

The relevance of the critical examination of Twardowski's works was obvious because of the position which he held in Polish academia even after his death. In fact, most Polish professors of philosophy in the interwar period were Twardowski's students. The situation did not change radically after the Second World War. According to Holland, the representatives of academic philosophy: Kotarbiński, Ajdukiewicz, and another famous Polish phenomenologist, Roman Ingarden (1893-1970), developed and disseminated the "myth" of the scientific exactness of Twardowski's research program. ${ }^{75}$ Twardowski himself had been a student of the prominent German philosopher Franz Brentano (1838-1917), and his interest in empirical psychology

72 [N.N.3] 1995, p. 88. This happened on March 27, 1950, see: Chudoba 2014, p. 75.

${ }^{73}$ Dembowski 1997, p. 306-307.

${ }^{74}$ Holland 1952, pp. 260-312. This article (in the extended version) was published later as a small book, see: Holland, 1953. In this text, I will refer to the journal version of Holland's publication.

${ }^{75}$ Holland 1952, pp. 260-263. 
became a good target for Holland's criticism. According to Holland, Twardowski followed Brentano, a former priest and theologian, and wanted to distract philosophy from the social and economic examination of objective reality and dealt with "psychological facts," which were in fact a cover for metaphysics.

Holland consequently wrote that he "could not deny himself the pleasure" of making the reader familiar with one of Twardowski's ideas "[...] from the field of Twardowski's 'clear and unambiguous' clarification of concepts, so admired by his students [...]." In the fragment quoted by Holland, Twardowski - in an article published in 1897 - argued that there is no proof that thinking is conducted exclusively with the brain, and psychology as a discipline could prevent philosophy from reducing itself to physiology. ${ }^{76}$ Following the spirit of his milieu, Holland was strict in his opinion: "One should not argue with a scholar who at the turn of the $19^{\text {th }}$ and $20^{\text {th }}$ centuries denies the fact that people are thinking with their brain - one should laugh at him." ${ }^{\prime \prime 7}$ Thus, all Twardowski's publications in which he disagreed with the theses of metaphysics not only seemed to Holland "non-scientific" but merely disguising the subjective idealism, which helped him to maintain the metaphysical way of thinking. The German publications of Twardowski, in which he characterized the reflection theory as a "primitive psychology," 78 gave Holland a rich source of material for proving that Twardowski opposed the "truly scientific" methods. ${ }^{79}$

Meanwhile, Twardowski's publications on the immortality of the soul were the most fertile ground for Holland's criticism. For him, it was obvious that by allowing the idea of the existence of God, Twardowski played into the hands of idealism. "Twardowski's argument against materialism and the defense of the Catholic faith was a sign of extraordinary obscurantism even for idealistic philosophy." 80 The tradition of the Lvov-Warsaw School was thus represented by "medieval"

76 Twardowski 1927, pp. 8-9.

${ }^{77}$ Holland 1952, p. 267.

${ }^{78}$ Of course, Twardowski did not know that this was Lenin's theory; he referred to the works of his opponents from the camp of empirical psychology (see Twardowski 1894, p. 67.)

${ }^{79}$ Holland 1952, pp. 272-278.

${ }^{80}$ Holland 1952, p. 288. 
and "scholastic" wordplays: "Twardowski's philosophy was not scientific but extremely obscure, fideistic, and clerical." ${ }^{81}$ Obviously, seeing Twardowski's approach as partisan ${ }^{82}$ Holland called the representatives of the Lvov-Warsaw School to join the "party of truth and historical materialism" and leave the "reactionary party" through "criticism and self-criticism." ${ }^{.83}$

\section{Władysław Tatarkiewicz and his History of Philosophy}

Following Chekhov's principle "if in the first act you have hung a pistol on the wall, then in the following one it should be fired," ${ }^{84}$ the last case of the campaign against the Lvov-Warsaw School will refer to a "specter" that was haunting the whole Stalinization process in Poland. The spirit of Zhdanov and his campaign against the Soviet philosopher Aleksandrov, which existed initially in the personal experience of Adam Schaff, materialized in the Polish translation (1951) of Zhdanov's speech delivered during the open discussion on Aleksandrov's History of Western Philosophy. ${ }^{85}$ The reference to the source of the inspiration for the whole campaign first appeared in the public discussion with the review of the History of Philosophy, written by one of Twardowski's students, Władysław Tatarkiewicz. By the time of the publication of the review, Tatarkiewicz had already been suspended from teaching. Meanwhile, the similarity between the cases of Tatarkiewicz and Aleksandrov was very superficial, even though both were formally criticized for their textbooks on the history of philosophy. Aleksandrov was a child of Stalinism, which had helped him to further his career. The campaign against Aleksandrov was rather a sign of the changes in Stalin's moods after the war and his wish to discipline the Soviet

${ }^{81}$ Holland 1952, p. 311.

${ }^{82}$ Lenin's usage of the word partijnost' was very unusual both for Russian and Polish and apparently represented the direct translation of the word Parteilichkeit into Russian, and meant both, as in German, engagement (see, for example: Vladimir I. Lenin [1905] 1967 , p. 138) and - just like in Russian - belonging to a party.

${ }^{83}$ Holland 1952, pp. 311-312.

${ }^{84}$ Ratcliffe (ed.) 2017.

85 Żdanow 1951. 
academia. Tatarkiewicz not only belonged to the non-Marxist LvovWarsaw School but he was also no stranger to the Catholic agenda and published his articles in Catholic journals even after the war. ${ }^{86} \mathrm{His}$ three-volume textbook on the history of philosophy could not thus go unnoticed among Stalinist activists.

The reviewer of Tatarkiewicz's work, Tadeusz Kroński, was also associated with the IKKN, though not as a student but as a teaching fellow and specialist in German thought. Additionally, Kroński had been a student of Kotarbiński and Tatarkiewicz at the University of Warsaw, where he had studied philosophy. This provided a special context for his critique of the Lvov-Warsaw School. Having stated that bourgeois history of philosophy and bourgeois philosophy are different issues, Kroński asked himself if the Tatarkiewicz's textbook could be allowed for academic practice in the new socialist Poland. Kroński thus determined the practical implication of his review, which had to "determine" if the book, written by a representative of the unwelcomed philosophical school, could have any relevance under the new political conditions. ${ }^{87}$ "Tatarkiewicz's textbook was no different than other bourgeois textbooks on the history of philosophy, but could this be useful in People's Poland?" 88

Having already learned which was the only "scientific history of philosophy," Kroński could easily show that Tatarkiewicz's work did not meet the key criteria of being scientific. Tatarkiewicz wrote his textbook as a traditional history of philosophical ideas without any attention to the "political and social views" of philosophers. Consequently, "the striking anti-historicism of Tatarkiewicz was," argued Kroński, "one of the sources of distortion of the development of philosophy in his textbook." ${ }^{99}$ The main mistake Tatarkiewicz was accused of by Kroński would be obvious to all familiar with the prominent Lenin's article Three sources and three components of Marxism..$^{90}$ Though, for Lenin, Marxism as a principle of human thought was rooted in German classical philosophy, English political economy, and French utopian socialism,

\footnotetext{
86 See, for example: Tatarkiewicz 1946, pp. 1-2.

87 Kroński 1952, p. 249.

88 Kroński 1952, p. 254.

89 Kroński 1952, p. 255.

90 Lenin [1913]
} 
none of these trends in the European thought received a proper place in Tatarkiewicz's History of Pbilosophy. ${ }^{91}$

The exclusion of philosophy from the broader scientific context did not allow Tatarkiewicz to see the roots of the materialist attitude of Thomas Hobbes, Baruch Spinoza, and - equally importantly Mikhail Lomonosov in the progress of natural sciences and the scientific worldview. Additionally, Kroński argued that the whole Renaissance tradition was not a philosophical phenomenon for Tatarkiewicz. He argued that "strict fanatic immanentism" in the selection of philosophical facts forced Tatarkiewicz to deny philosophical originality to the Renaissance," while, according to Kroński, this period was extremely productive for the development of the materialist worldview. ${ }^{93}$ More importantly, Tatarkiewicz - who was finishing his book after the war - "falsified," according to Kroński, the real history of materialism through attempts to portray such Christian thinkers as Tertulian and Thomas Aquinas as materialists. ${ }^{94}$ Tatarkiewicz's distinction between "minimalist" and "maximalist" tendencies in philosophy also provoked strict criticism. ${ }^{95}$ Tatarkiewicz introduced these concepts to define thinkers who spoke exclusively about real objects and those who attempted to make broader suggestions, respectively. This strategy seemed to Kroński to attempt to legitimize non-scientific tendencies in philosophy and demonstrated "the deeply reactionary character" of Tatarkiewicz's program. ${ }^{96}$

The key section of the review contained a direct reference to Zhdanov and concerned cosmopolitanism. According to Kroński,

91 According to Kroński, all socialist thinkers were for Tatarkiewicz only sociologists but not philosophers: Kroński 1952, p. 256.

${ }^{92}$ With "immanentism” Kroński meant a non-historical logic of Tatarkiewicz's approach.

${ }_{93}$ Kroński 1952, pp. 257-259.

${ }^{94}$ Kroński 1952, p. 260.

${ }^{95}$ It is noteworthy that the discussion on "maximalist" and "minimalist" tendencies (albeit in a different context) was an important topos of Catholic public discussion in the early post-war period. Then, the debate was provoked by Stanisław Stomma with his article on Emmanuel Mounier's strategy of collaboration between Marxists and Catholics. The concepts of "minimalism" and "maximalism" referred not only to metaphysical issues but also to the limits of what was acceptable when seeking to compromise with the new realities, see: Pazik 2019, pp. 22-25.

${ }^{96}$ Kroński 1952, p. 260. 
although the three volumes contained 1,362 pages, only 43 of them were devoted to Polish philosophy. More importantly, there was no word about Russian philosophy in the History of Philosophy, which could be regarded as intentional. Kroński argued that the reason why Tatarkiewicz avoided speaking about Polish philosophy was his wish to conceal that Polish non-fascist thinkers, such as Edward Dembowski (1822-1846) and Henryk Kamieński (1813-1866), were revolutionaries. Additionally, in his view, a thinker with Catholic sympathies could not be an author of an "objective" history of philosophy because of his fear of losing popularity in nationalist circles. The hatred towards progressive and socialist views, wrote Kroński, was also a reason for the exclusion of Russia and the Soviet Union from Tatarkiewicz's narrative:

In [his] hatred of the Soviet Union and the constant fear of this natural ally [of Poland] and its support for the broad working masses of the [Polish] nation, [Tatarkiewicz] feverishly sought evidence of [Polish thought] belonging to the 'Christian,' 'European,' 'Western' culture, thinking that with the help of this propaganda it would be possible to sever the quiet natural bond that connects the Polish nation with the Russian one. ${ }^{97}$

The fact that Tatarkiewicz started the third volume of his History with an intention to devote a separate volume to the philosophy of Slavic countries ${ }^{98}$ was not a problem for Kroński. He warned against naivety in looking for cosmopolitans among scholars, when he wrote:

Cosmopolitans are not always those who do not want to write about their own nation's culture - you can be a good patriot and study e.g. Spinoza or Thomas Aquinas your whole life - they are first of all those who do but without specifying its rightful position in the world. ${ }^{99}$

More importantly, Kroński literally copied the argument of Zhdanov from his speech against the Marxist Aleksandrov, concerning the

${ }^{97}$ Kroński 1952, p. 266.

98 Tatarkiewicz 1950 , p. 6.

99 Kroński 1952, p. 269. 
underestimation of the role of Marxism in the history of philosophy. Even though Tatarkiewicz never defined himself as a Marxist, Kroński critically remarked that readers of his History may get the impression that Marxism was only one of many philosophical trends rather than the only scientific method. Kroński thus concluded that the Tatarkiewicz's work could not be useful for the new socialist state, especially for the education of the new generation of Polish philosophers. ${ }^{100}$

\section{The right for a "supervised" response}

Even though Adam Schaff and his group did their best to explain what the correct way of responding to criticism was, the representatives of the Lvov-Warsaw School did not seem ready to follow the prescriptions of self-criticism and convert to Marxism. They were not very deeply familiar with the Soviet culture of "academic debate"101 and continued acting as if discussion implied an exchange of arguments between representatives of different attitudes. Schaff had to work with another academic culture and needed to find a way to address this issue without the purges that had helped to "discipline" the Soviet academy in the 1930s. Kotarbiński and Ajdukiewicz, who continued teaching at Polish universities, were allowed to publish their responses to the criticisms both against their own works and the whole academic tradition of the Lvov-Warsaw School. Nevertheless, the ultimate aim to turn Polish academia Marxist was not forgotten. The publications of the philosophers were accompanied by extensive comments from the editorial board and a special article by one of the scholars with the "correct views." These measures were obviously aimed at defending the readers, who were not reliable in their new faith to fight the temptation to agree with the logicians.

Responding to Baczko's arguments, who had argued that Kotarbiński's version of materialism was, in fact, idealism, Kotarbiński wrote: "[to say that] my works contain some traits of materialism [is just as correct as] to say that the worldview of a regular parish priest contains certain traits of Catholicism." ${ }^{102}$ Moreover, Kotarbiński did not hesitate to say:

${ }^{100}$ Kroński 1952, p. 271.

101 Kojevnikov 1998, pp. 25-52; Matveev 2020, pp. 113-124.

102 Kotarbiński 1952a, p. 315. 
"I dare say that [my pansomatic semantics are] the only consistently materialistic semantics on these territories." He argued that his attempts to rationalize the academic discourse and his idea to represent words as bodies were the most effective path towards materialism. Concerning the accusations of speculation with words replacing research on objective phenomena, Kotarbiński briefly remarked that he "never participated in such a 'party' [sic!]" and did not see the necessity to refute something he never said. Meanwhile, the accusation of conventionalism was, according to Kotarbiński, the key argument of his critics; he likened the situation to bombardment: "like a bomber circling around this area -with the critic inside, angrily throwing bombs on me". ${ }^{103}$ With two options in front of him, i.e. "to fire back" or "to wave a white flag," Kotarbiński chose the former and thus disregarded the kind of answer that was Schaff's group would recommend.

Kotarbiński confessed that he did not understand what his critic meant by accusing him of separating language from the socio-historical context: "I am utterly convinced that, historically speaking, language is a social construct. As a former teacher of classic philology, the building blocks of the historical and philological catechism are deeply rooted in my mind." 104 Additionally, Kotarbiński strongly denied that he held a mechanistic vision of the world and emphasized that "one of the labels on my traveling suitcase always said 'Be careful! Mechanical bias!'” Thus, having replied to the accusation of his program not being historical, Kotarbiński allowed himself a certain witticism towards his critic. He said that Baczko had accused him of metaphysical character of his research program, though "in a very specific Marxist understanding of this word." In fact, according to Kotarbiński, Baczko created "a mannequin, a wax figure" replacing his real dynamic and practical approach, and then repeatedly attacked this dummy. ${ }^{105}$ Regarding dialectics, which represented the core of historical materialism, Kotarbiński argued that his research program had no contradictions with this discipline, which he understood as a framework for explaining the process of development. ${ }^{106}$ Kotarbiński thus attempted, on the one

\footnotetext{
103 Kotarbiński 1952, pp. 318-319.

104 Kotarbiński 1952, p. 319.

105 Kotarbiński 1952, p. 322.

106 Kotarbiński 1952, p. 223.
} 
hand, to refute the key points of his opponent, and on the other hand, to show that historical materialism, which was depicted on the "red flag" of Schaff's group, referred to other issues than logic and could not be a criterion for judging logical studies.

Continuing his article, Kotarbiński made an important clarification concerning the entire philosophical tradition in Poland. According to him, the very concept of the Lvov-Warsaw School, which had become the object of criticism, led to confusion. He found it more accurate to speak about two different schools: the Lvov school and the Warsaw school. While Twardowski, a teacher of most of the Polish philosophers, was a philosopher in the full sense of the word, his students who developed logic in Warsaw made it under the banner of "anti-philosophy." This division was necessary for Kotarbiński to show that Twardowski's engagement in the debates on ontological issues was foreign to the Warsaw philosophers, who wanted to conduct concrete research while avoiding vague philosophical categories. While the Warsaw school dealt with mathematical logic, Twardowski strove to make philosophy more scientific, though not in the English and French sense of the word science, but rather the German Wissenschaft. ${ }^{107}$ Kotarbiński recognized that the ontological tendencies in Twardowski's program, "from the sociological point of view, could be labelled as escapism." Nevertheless, he emphasized that Twardowski was "extremely tolerant" and did not force his agenda on his students. ${ }^{108} \mathrm{In}$ this way, Kotarbiński tried to challenge the homogeneity of the object of criticism. Opposed to reducing the whole philosophical agenda to the competition between Marxist and bourgeois philosophies, which was the driving force of Schaff's campaign, Kotarbiński followed his virtue of academic discussion and identified the phenomena that were different.

In the concluding part of his publication, Kotarbiński discussed "the issues of good and evil," which characterized his axiological attitude in the new political situation. He remembered that one of the key arguments of his critics was his unwillingness to change his views despite the changes in the social structure of the Polish state. Kotarbiński did

${ }^{107}$ Kotarbiński obviously meant the influence of Edmund Husserl and his project of philosophy as rigorous science (Husserl 1910), see: Kotarbiński 1952a, p. 329.

${ }_{108}$ Kotarbiński 1952a, p. 328. 
not hide his irony when he wrote that his views "have ossified and do not move, even though the society rushes forward, carried away by the progressive movement." In an obvious reference to the campaign promoted by Adam Schaff, Kotarbiński wittily remarked: "it is true that I do not participate in the class struggle organized politically $[\ldots]$ but it is not true that I am out of practice." Kotarbiński argued that he was ready to improve his views but only when these improvements would correspond with his moral convictions, otherwise he preferred to characterize the changes required by his critics as opportunistic. He referred to the example of Socrates, whose views maintained their relevance despite all the political and social changes that had happened over thousands of years. Without compromising his key moral principles, Kotarbiński as an "academic liberal" was ready to serve "the new socialist academia and to participate in the education of proletariat." 109 Thus, Kotarbiński thematized the difference between himself and Schaff's group not only in terms of academic discussion but also over the moral issues: the basic virtues of truth and the academic (public) role of the scholar.

None other than the sociologist Józef Chałasiński ${ }^{110}$ was chosen to defend the readers of Mysl Filozoficzna from the negative influence of Kotarbiński's response. It is no coincidence that Chałasiński, who was forced to change his views with a response sensitive to the fluid political reality, ${ }^{111}$ showed particular diligence in proving that the postwar publications of Kotarbiński contained no response to the social changes in post-war Poland. Chałasiński, who a few years earlier had flaunted his liberalism, ${ }^{112}$ wrote that Kotarbiński's concept of reism was interesting to him only as a form of "liberal and individualistic escape"

109 Kotarbiński 1952, p. 329-330.

${ }^{110}$ Chałasiński was one of the central figures of Polish sociology in the early post-war years. Developing his sociological program, Chałasiński criticized Marxism as a very limited approach. With the dawn of Stalinisation, Chałasiński replaced Kotarbiński as rector of the University of Lódź and radically changed his discourse on Marxism. See: Lokhmatov 2020, pp. 524-528.

111 Chałasiński could be an example of a "correct" response to the criticism against his discipline. He not only recognized the falsity of the whole tradition of sociology but also harshly criticized his own interwar publication as reactionary. See: Chałasiński 1951, pp. 75-105.

${ }^{112}$ Lokhmatov 2020, p. 530. 
from historical reality and as a "claim for moral purity of the historical role of scholars in our revolutionary epoch." ${ }^{113}$ Readers of Chałasiński's texts from the times immediately after the war ${ }^{114}$ would be surprised to find the following lines in an article by the same author a few years later:

the [social and moral] criteria of these liberal moralists $[\ldots]$ were in certain moral disagreement with capitalism but, after various moral reservations, the solidarity with the dictatorship of capitalism [...] is their moral catastrophe. ${ }^{115}$

Developing this idea, Chałasiński directly accused Kotarbiński of opposing the new political realities. Chałasiński went beyond the texts written by his opponent and referred to the oral presentation delivered by Kotarbiński at the meeting of the Lódź Scientific Society: "concerning the Marxist movement, he [Kotarbiński] said that every scholar had to take from this movement elements that corresponded with their conscience." ${ }^{116}$ The reference to conscience was especially irritating for Chałasiński. He argued:

none of those who wanted to take part in the reconstruction [of Poland into a socialist state] could escape selfdetermination towards the theory and methodology of historical materialism.

Chałasiński concluded his text with an expressive point:

A conscience of an intellectual that is detached from the course of history is a broken compass. It is not to be trusted when, in order to avoid a decision, it says that $[\ldots]$ there is a compromise, a third "gentlemanly" path ... a path of the peace of conscience. There is no third way. History has drastically simplified the matter of choice. There is either the path of criminal capitalism or "socialist revolution". ${ }^{117}$

113 Chałasiński 1952, pp. 309, 310.

${ }^{114}$ In which Chałasiński criticized Marxism, see Lokhmatov 2020, p. 524-528

115 Chałasiński 1952, p. 312.

116 Chałasiński 1952, p. 313.

117 Chałasiński 1952, p. 314. 
This "commentary" by Chałasiński was published in the volume before the response of Kotarbiński, although it contained the criticism of Kotarbiński's text which was supposed to be read later. Additionally, the readers of the journal, when she or he - despite all the warnings read Kotarbiński's article, had to face the section From the editorial board. ${ }^{118}$ In the text apparently written by Schaff or, at least, under his close guidance, the editorial board made clear that this was the end of the debate on the views of Kotarbiński. ${ }^{119}$ Having reviewed the pro et contra arguments of Kotarbiński's research program, the editorial board expressed regret that the philosopher remained stubborn and claimed "only partial solidarity" with historical materialism. Even though Kotarbiński had thus failed to conduct "critical and self-critical examination" and continued to promote "views whose fallacy has been demonstrated," "20 Schaff's group took on this role and suspended Kotarbiński from publishing other "erroneous" articles.

Nevertheless, Kotarbiński's name appeared in the discussion on the heritage of the Lvov-Warsaw School once again. This time, Kotarbiński attempted to defend his teacher Kazimierz Twardowski against the criticism of Henryk Holland. There was no place for such a contribution in the main part of the journal anymore, and the form of Kotarbiński's response is a noticeable trait in this discussion. The opinion of Kotarbiński was published in the section "Letters to the editorial board." Nevertheless, the tone of this text had changed since his previous contribution, which was full of witticisms. This time, Kotarbiński was clearly annoyed. He characterized Holland's article as abusive and wrote that the "contempt, mockery, and humiliation" of Twardowski, which were published in Holland's article, were unacceptable. More importantly, he claimed that the editorial board should watch the language of their publications and reflect on what kind of discussion they were promoting. ${ }^{121}$ The editorial board was apparently concerned by Kotarbiński's pressure and even recognized that they probably had to remove "some of the cruelest" passages from Holland's contribution. Nevertheless, the editorial board clarified again

\footnotetext{
${ }^{118}$ [N.N.4] 1952, pp. 331-337.

${ }_{119}$ [N.N.4 1952 , p. 331.

${ }^{120}$ [N.N.4 1952 , p. 337.

121 Kotarbiński 1952b, pp. 356-358.
} 
that their idea of scholarly discussion implied the struggle against the bourgeois and idealistic attitude. Thus, the cruelty could be understood as an instrument of this struggle. ${ }^{122}$

Kazimierz Ajdukiewicz also had an opportunity to respond to Adam Schaff's criticism towards his research program. As with Kotarbiński, Ajdukiewicz attempted to rationalize the arguments that were used by Schaff. Not without witticism, Ajdukiewicz wrote that "after reading [Ajdukiewicz's ideas in Schaff's interpretation], the reader of prof. Schaff's article would get a tremendously unflattering opinion on [Ajdukiewicz's] mental state." ${ }^{123}$ In the best tradition of his discipline, the logician Ajdukiewicz systematized Schaff's accusations and replied to them in a detailed manner. In fact, Ajdukiewicz only repeated the key points of his research program. He showed that the thesis of "radical conventionalism" was rooted not in idealism, which Schaff desired to find in his publications, but in the nature of the language. At the same time, Ajdukiewicz pointed out that he never argued for fetishization of language or a break with the social reality in logical studies. ${ }^{124}$ More importantly, Ajdukiewicz did not exhibit any signs of progress in comprehending the role of Marxism-Leninism as the "only scientific method." Nevertheless, he continued to argue that he did not see any essential contradictions in his approach with "the doctrine of Marxism." He wrote: "[...] prof. Schaff's criticism did not convince me of a need to revise any of my scrutinized opinions from this article," and added, "I even think that some of my works [...] would not be without relevance for the justification of the Marxist method in practicing philosophy." 125 The main argument of Ajdukiewicz was simple: "The issues with which I was dealing and the issues with which Marxist philosophers were dealing are different. Different issues require different methods." 126

In this discussion, Ajdukiewicz received gentler supervision than was the case with Kotarbiński. To conclude the debate on the LvovWarsaw School, Leszek Kołakowski (1927-2009), then one of the activists in Schaff's institute and later one of the key European

${ }^{122}$ Kotarbiński 1952b, pp. 357-358.

123 Ajdukiewicz 1953, p. 292.

124 Ajdukiewicz 1953, pp. 292-315.

125 Ajdukiewicz 1953, p. 316.

126 Ajdukiewicz 1953, p. 334. 
anti-Marxist thinkers, ${ }^{127}$ was chosen to comment on Ajdukiewicz's response. Kołakowski's delivery was noticeably more polite than that of his colleagues from the IKKN. Of course, all necessary concepts such as "reactionary character," "bourgeois idealism," or "the class nature of Ajdukiewicz's ideas" were present in Kołakowski's comment. Nevertheless, these descriptions did not play a crucial role in the argumentation. Criticizing conventionalism, Kolakowski formulated the ideas that had attracted the young intellectuals from his milieu to the campaign headed by Adam Schaff. Yet, most of them, several years later, would find themselves among the resolute opponents of the regime.

Following the deductive method, Kołakowski conducted an indepth examination of various approaches to conventionalism. ${ }^{128}$ Based primarily on the works of the prominent mathematician and philosopher Édouard Le Roy (1870-1954), the mathematician and astronomer Henri Poincaré (1854-1912), and the physician and historian of science Pierre Duhem (1861-1916), Kołakowski emphasized their relativism towards the possibility to grasp objective reality and the constructivist approach to the definition of scientific facts. ${ }^{129}$ Kolakowski argued that the issue of truth is the key contradiction between conventionalism and Marxism. Nevertheless, truth itself was not a key issue for Kołakowski. According to him, it was experience and not objective reality as a criterion for truthfulness that made science helpless in its struggle against prejudices. Kołakowski, who many years later, would be considered a philosopher of religion, ${ }^{130}$ claimed in 1953 that the rejection of objective truth, coupled with agnosticism, led to "bourgeois scientists" not being able to find arguments in their struggle against religion, which was their

${ }^{127}$ He was the author of a fundamental work on the history of Marxism: Kołakowski 1978. Of course, the role of Kolakowski in Schaff's group as well as in the intellectual life of post-war Poland was much larger than it might appear from the materials of this discussion. Kołakowski's intellectual evolution could serve as an illustration of the radical changes in the ideas of all those members of Schaff's group who, several years later, would become the key critics of the regime. See e.g.: Mentzel 2020.

128 Kołakowski 1953, pp. 335-373.

${ }^{129}$ It is striking that Kolakowski did not mention the book of the Polish biologist Ludwik Fleck (Fleck 1935), which is currently regarded as a key work in the field of constructivist approach to social facts.

${ }^{130}$ See e.g. the collection of his essays published by the Catholic published Znak: Kołakowski 2019. 
main goal. ${ }^{131}$ The works of Lenin thus seemed to Kołakowski and many of his colleagues to be a much more effective tool in their struggle against the "obscurantism," 132 which they had faced in interwar Poland and wanted to destroy under the new political conditions, than all the doubts in the possibility of knowledge. All this led Kołakowski to the point - commonly shared by Schaff's group - that Ajdukiewicz's works were a part of conventionalist agenda representing an "idealistic and erroneous philosophy." Only the belief in the objective truth could help science to complete its mission, argued Kołakowski, 'waking people have one common world and each come back to her or his own world only while sleeping. ${ }^{133}$

\section{Conclusion}

The campaign organized by Schaff's group did not achieve its aim. Even though the exchange of arguments from both sides formally took place, none of the participants in the discussion showed any movement in his position towards the position of his opponents. The reason for this is the obvious difference in understanding the very idea of academic discussion. From Schaff's perspective, philosophy was a field of political struggle, and thus the basic virtue of a philosopher was to be effective in this struggle. The unity of all scholars was the marker of success in the competition between idealism and materialism, which was more than real for Schaff. The "young guard" of Schaff's institute was inspired by the project of "people's democracy" that was proclaimed in Poland after the Second World War. For young socialists, a great opportunity that opened up in the post-war realities was the ability to fight against obscurantism, which, in their view, had surrounded them in inter-war Poland and was embodied, primarily, in Catholicism.

So, while the aim of their academic activism was to find more effective tools in their struggle against obscurantism, the effectiveness in this struggle was the main criterion for the formation of the basic virtues in scholarly activity and academic discussion. Therefore, seeking out elements of idealism in the heritage of the Lvov-Warsaw School

131 Kołakowski 1953, pp. 335-373.

132 Kołakowski 1953, p. 351.

133 Kołakowski 1953, p. 372. 
proposed by Schaff could meet their expectations as a measure to make Polish academia more effective in this fight. Even though the fervor and brutality of the young intellectuals in their discourse depended on their character and personal relationships with the prominent logicians, the general idea of science/scholarship in the form of oppositions, such as science vs. religion, enlightenment vs. obscurity, materialism vs. idealism, could have contributed to their inspired engagement in Schaff's project.

For the logicians from the Lvov-Warsaw School all this was not a key criterion at all. Their idea of the academic discussion was different. They all never tired of repeating that rationality, the opposite of obscurantism, or even materialism, played an important role in their research and political agenda. Nevertheless, though the struggle against obscurantism was a part of their academic activity, they did not see any point in resolving the ontological contradictions between idealism and materialism. The fight against religion was neither an aim in itself nor a function of science/scholarship in their axiology, because they saw no point in answering questions about God's existence. Their research was determined by the academic agenda and by the reflections on the possibilities of knowledge. More importantly, academic discussion as an exchange of arguments was, for them, the only precondition for academic development. This kind of discussion had to divide questions into pointless and relevant ones and thus lead to rationalization. Therefore, during the whole campaign, the logicians attempted to translate the accusations against them into arguments and to respond to the concrete points that were extracted from the polemic texts of their opponents written in another genre. In this way, they attempted to promote their approach to academic discussion and did not succumb to the pattern prescribed by the editorial board of Myśl Filozoficzna.

Nevertheless, in terms of the objectives formulated by Schaff's group, only one kind of discussion could be considered successful self-criticism and repentance for holding incorrect views. In a sense, the very attempt of the logicians to take the arguments of their opponents out of the context of their fighting spirit was a methodological flaw. The ideas promoted by Schaff's group did not work and were not supposed to work beyond the paradigm of political mobilization for the struggle against ideological enemies. Nevertheless, Polish land showed again that it was not fertile to this approach to academic debate. None of the philosophers who became subjects of Schaff's campaign lost their 
position in Polish academia. Kotarbiński, Ajdukiewicz, and Tatarkiewicz maintained their full membership of the Polish Academy of Sciences (an institution created during Stalinization). Moreover, a few years later, the "young guard" from Schaff's institute would come to fight against the virtues promoted by Stalinism. ${ }^{134}$ The "defeat" of Schaff's campaign would determine the peculiarity of the Polish academic landscape until the collapse of the socialist regime in Poland.

\section{Bibliography}

Adam Schaff 2003: Nie ma innej drogi (interview). Available online (29.05.2020): https://www.youtube.com/watch?v $=$ mMBkGFEukq4.

Adam, Schaff 1997: Moje spotkania ₹ nauka polska, Warszawa: Polska Oficyna Wydawnicza BGW.

Adibekov, Grant M. 1998: Soveshhanija Kominforma 1947, 1948, 1949. Dokumenty i materialy. Moskva: Rosspen.

Ajdukiewicz, Kasimir 1934: Das Weltbild und die Begriffsapparatur. Erkenntnis 4, pp. $259-287$.

Ajdukiewicz, Kasimir 1934: Sprache und Sinn, Erkenntnis 4, pp. 100-138.

Ajdukiewicz, Kasimir 1935: Die Wissenschaftliche Weltperspective. Erkenntnis 5, pp. 22-30.

Ajdukiewicz, Kazimierz 1937: Problemat transcendentalnego idealizmu w sformulowaniu semantycznym. Przeglad filozoficzny III, pp. 271-287.

Ajdukiewicz, Kazimierz 1946: O tzw. Neopozytywizmie. Myśl Wspótczesna 6-7, pp. $155-176$.

Ajdukiewicz, Kazimierz 1953: W sprawie artykułu prof. A. Schaffa o moich pogladach filozoficznych. Myśl filozoficzna 2, pp. 292-334.

Aleksandrov, Grigorij F. 1946: Istorija zapadnoevropejskoj filosofii. Moskva. Leningrad: Izdatel'stvo AN SSSR.

Baczko, Bronisław 1951a: O poglądach filozoficznych i społeczno-politycznych Tadeusza Kotarbińskiego. Myśl filozoficzna 1-2, pp. 247-289.

Baczko, Bronisław 1951b: O pogladach filozoficznych i spoteczno-politycznych Tadeusza Kotarbińnkiego, Warszawa: TKKN.

${ }^{134}$ Connelly 1996, p. 338-344. 
Bińko, Beata 1996: Instytut Kształcenia Kadr Naukowych przy KC PZPR narzędzie ofensywy ideologicznej w nauce i szkolnictwie wyższym. Kultura i Spoteczeństwo 2, pp. 199-214.

Borejsza, Jerzy 1945: Rewolucja łagodna. Odrodzenie 10-12, p. 1.

Brożek, Anna \& Chybińska Alicja (eds) 2016: Fenomen Szkoły Lwowsko-Warszawskiej. Lublin: Wydawnictwo Academicon.

Budzynska, Celina 1952: Krytyka i samokrytyka niezawodny oręż partii. Nowe Drogi 7, pp. 117-127.

Chałasiński, Józef 1951: Z zagadnień metodologii badań społecznych. Myśl Filozoficzna 1, p. 75-105.

Chałasiński, Józef 1952: Rzecz z powodu „Humanistyki bez hipostaz”. Myśl Filozoficzna 2, pp. 303-314.

Chudoba, Wiesław 2014: Leszek Kołakowski. Kronika sycia i drieła. Warszawa: Wydawnictwo IFiS PAN.

Chwedeńczuk, Bohdan 2005: Dialogi z. Adamem Schaffem. Warszawa: Iskry.

Connelly, John 1996: Internal Bolshevisation? Elite Social Science Training in Stalinist Poland. Minerva 34 (4), pp. 323-346.

Daston, Lorraine; Galison, Peter 2007: Objectivity. New York: Zone Books.

Daston, Lorraine 1994: Historical epistemology. [In:] Chandler, James, Davidson, Arnold, Harootunian, Harry (ed.) 1993: Questions of evidence: Proof, practice, and persuasion across the disciplines. Chicago: University of Chicago Press, pp. 282-289.

Dembowski, Bronisław 1997: Spór o metafizyke i inne studia z historii filozofii polskiej, Włocławek: Włocławskie wydawnictwo diecezjalne.

Drabek, Anna; Woleński, Jan; Radzki, Mateusz M. 2019: Interdisciplinary Investigations into the Lvov-Warsaw School. London: Palgrave Macmillan.

Fleck, Ludwik 1935: Entstehung und Entwicklung einer wissenschaftlichen Tatsache. Einführung in die Lehre vom Denkstil und Denkeollektiv.

Garrido, Ángel \& Wybraniec-Skardowska, Urszula (eds.) 2018: The Lvov-Warsaw School. Past and Present, Basel: Birkhäuser.

Holland, Henryk 1952: Legenda o Kazimierzu Twardowskim. Myśl Filozoficzna 3, pp. 260-312.

Holland, Henryk 1953: Legenda o Kazimierzu Twardowskim, Warszawa: Książka i Wiedza.

Hübner, Piotr 1983: I Kongres Nanki Polskiej jako forma realizacji założén polityki naukowej państwa ludowego, Wrocław: Zakład Narodowy im. Ossolińskich. 
Husserl, Edmund 1910: Philosophie als strenge Wissenschaft.

Juchnowski, Sebastian 2019: Krytyka konwencjonalizmu w myśli Leszka Kołakowskiego w pierwszej połowie lat pięćdziesiątych. Wrocławskie Studia Politologiczne 27, pp. 54-72.

Khlevnuk, Oleg. V. 2015: Stalin: New Biography of A Dictator. New Heaven \& London: Yel University Press.

Kojevnikov, Alexei 1998: Rituals of Stalinist Culture at Work: Science and the Games of Intraparty Democracy circa 1948. The Russian Review 57, pp. 25-52.

Kojko, Jerzy 2009: Polskie spory filozoficzne w latach 1945-1949. Zeszyty naukowe Akademii Marynarki Wolnej 4 (179), pp. 101-144.

Kolakowski, Leszek 1978: Main Currents of Marxism. Vol. I: The Founders. Vol. II: The Golden Age. Vol. III: The Breakdown, trans. P.S. Falla. Oxford: Oxford University Press.

Kołakowski, Leszek 1953: Filozofia nieinterwencji. Myśl Filozoficzna 2, pp. 335-373.

Kołakowski, Leszek 2019: Chrześcijaństwo. Kraków: Znak.

Kotarbiński, Tadeusz 1925: Logika dla nauczycieli a logika matematyczna. Ruch filozoficzny IX (9-10), pp. 519-532.

Kotarbiński, Tadeusz 1929: Elementy teorii poznania, logiki formalnej i metodologii nauk. Lwów: [n/p].

Kotarbiński, Tadeusz 1935: Zasadnicze myśli pansomatyzmu. Præeglad Filozoficzny 1935 IV, pp. 139-148.

Kotarbiński, Tadeusz 1952a: Odpowiedź. Myśl filozoficzna 2, pp. 315-330.

Kotarbiński, Tadeusz 1952b: Listy do redakcji: W sprawie artykułu „Legenda o Kazimierzu Twardowskim”. Myśl filozoficzna 2, pp. 356-358.

Kroński, Tadeusz 1952: O „Historii filozofii” W. Tatarkiewicza, Myśl Filozoficzna 4, pp. $249-272$.

Kotarbiński, Tadeusz; Kuźnicka, Maria 2006: Poczta do Karmelu. Korespondencja Tadeusza Kotarbińskiego i Marii Kuźnickiej z lat 1945-1973. Opracowanie: Stanisław Borzym, Antonina Majkowska-Sztange. Warszawa: Instytut Filozofii i Socjologii PAN.

Kuryła, Mateusz 2018: Adam Schaff - droga do komunizmu (1913-1939). Przeglad Humanistyczny 3, pp. 167-189.

Lenin, Vladimir I. [1905] 1967: Polnoe sobranie socbinenij. Moskva: Izdatel'stvo politicheskoj literatury, vol. 12.

Lenin, Vladimir I. 1913: The Three Sources and Three Component Parts of Marxism. Available online (11.05.2020): https://www.marxists.org/archive/lenin/ works $/ 1913 / \mathrm{mar} / \mathrm{x} 01 . \mathrm{htm}$. 
Lokhmatov, Aleksei 2020: Auf dem Weg zur "Einheit": Józef Chałasiński und die Suche nach einer "erlaubten” Genealogie der Soziologie im Nachkriegspolen (1945-1951). NTM Zeitschrift für Geschichte der Wissenschaften, Technik und Medizin 28(4), pp. 519-546. Available online: https://link.springer.com/content/ pdf/10.1007/s00048-020-00267-3.pdf.

Matveev, Sergej R. 2020: “Uchenyj-bol'shevik prizvan ocenivat' objektivno”: recenzii v sovetskoj istoricheskoj periodike 1930-1950-h godov. [In:] Natal'ja M. Dolgorukova, Alexei A. Pleshkov (eds.), Nauchnoe recenzirovanie v gumanitarnyh disciplinah. Moskva: Izdatel'skij dom NRU HSE, pp. 113-124.

Mentzel, Zbigniew 2020: Kołakowski. Czytanie świata. Biografia. Kraków: Znak.

[N.N.1] 1953: I Kongres Nauki Polskiej. Warszawa: Państwowe Wydawnictwo Naukowe.

[N.N.2] 1951: Od Redakcji. Myśl Filozoficz̨na 1-2, pp. 7-15.

[N.N.3] 1995: List grupy uczestników seminarium filozoficznego profesora Władysława Tatarkiewicza. Przeglad Filozoficzny 2, pp. 88-90.

[N.N.4] 1952: Od Redakcji. Myśl filozoficzna 2, pp. 331-337.

Ostrowski, Adam 1945: Hugo Kołłątaj i łagodnia rewolucja 1791. Ku乏́nica 4-5, pp. 11-13.

Paul, Herman 2011: Distance and Self-Distanciation: Intellectual Virtue and Historical Method Around 1900. History and Theory 50(4), pp. 104-116.

Paul, Herman 2019: How to Be a Historian: Scholarly Personae in Historical Studies, 1800 -2000. Manchester: Manchester University Press.

Pazik, Przemysław 2019: Spory i wybory ideowe katolików swieckich w okresie narodzin komunistycznego systemu władzy w Polsce (1945-1948). Warszawa: (the manuscript of $\mathrm{PhD}$ thesis).

Pinkus, Benjamin 1974: Soviet campaigns against "Jewish Nationalism" and "Cosmopolitism", 1946-1953. Soviet Jewish Affairs 4(2), pp. 53-72.

Pomian, Krzystof 2018: W'śód mistrzów i prayjaciół. Gdańsk: Słowo/Obraz terytoria.

Ratcliffe, Susan (ed.) 2017: Oxford Essential Quotations (5 ed.). Oxford University Press. eISBN: 9780191843730. Available online: https://www.oxfordreference. com/view/10.1093/acref/9780191843730.001.0001/q-oro-ed5-00002871.

Salmonowicz, Stanisław 2003: Profesorowie i studenci w dobie stalinizmu w Polsce (19441956). In: Miernik, Grzegorz (ed.), Polacy wobec PRL. Strategie praystosowawcze. Kielce: Kieleckie Towarzystwo Naukowe, pp. 75-92.

Schaff, Adam 1952: Poglądy filozoficzne Kazimierza Ajdukiewicza. Myśl Filozoficzna 1, pp. 209-256. 
Stalin, Joseph 1950: Marxism and Problems of Linguistics. [In:] Stalin Reference Archive. Availbale online: (28.05.2020): https://www.marxists.org/reference/ archive/stalin/works/1950/jun/20.htm.

Tatarkiewicz, Władysław 1946: Szczęście ludzi przyszłych. Tygodnik Warszawski 17, pp. 1-2.

Twardowski, Kazimierz 1894: Zur Lehre vom Inhalt und Gegenstand der Vorstellungen. Eine psychologische Untersuchung. Wien: [n/p].

Twardowski, Kazimierz 1927: Rozprawy i artykuły filozoficzne. Lwów: [n/p].

Wierzbicki, Andrzej 1993: Konstytucja 3 Maja w historiografii polskiej. Warszawa: dawnictwo Sejmowe.

Zegzuła-Nowak, Joanna 2010: Polemiki Adama Schaffa z Kazimierzem Ajdukiewiczem jako prayktad walki ideologicznej marksistón ze Szkoła Lwowsko-Warszawsk.a. [In:] Słomski, Wojciech (ed.), Jezyle i poznanie: $w$ 120. rocznice urodzin Kazimierza Ajdukiewicza. Warszawa: Wydawnictwo Wyższej Szkoły Finansów i Zarządzania, pp. 257-266.

Zhdanov, Andrej A. 1952: Vystuplenie na diskussii po knige G.F. Aleksandrova "Istorija Zapadnoevropejskoj Filosofii” 24 ijulja 1947. Moskva: Gospolitizdat.

Zubkova, Elena 1998: Russia After the War: Hopes, Illusions and Disappointments, 1945-1957 (translated by Hugh Ragsdale). London \& New York: Routledge.

Żdanow, Andrzej A. 1951: Przemówienie wygtoszone w dyskusji nad ksiażka G. Aleksandrowa „Historia zachodnioeuropejskiej filozofii” 24 czerwca 1947 r. Warszawa: Książka i Wiedza. 